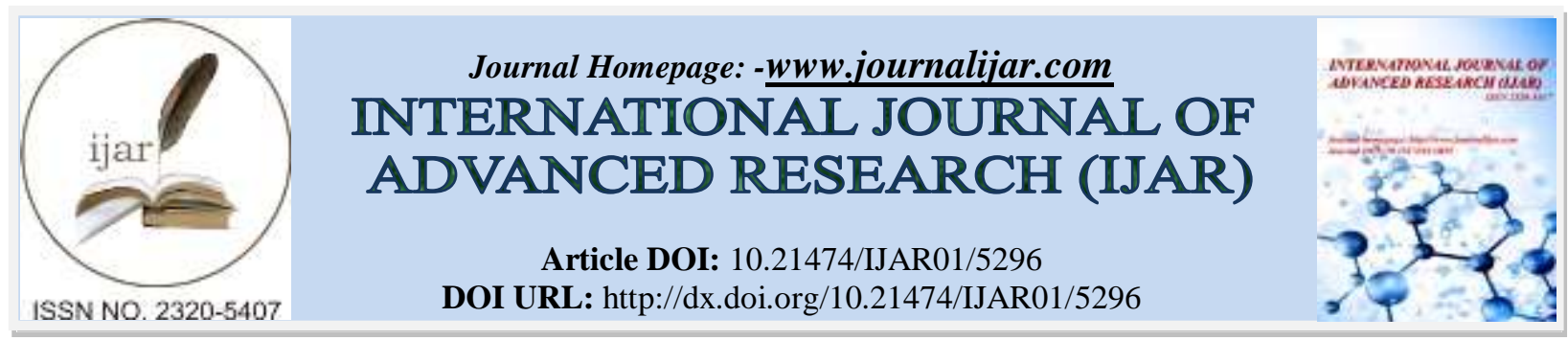

RESEARCH ARTICLE

\title{
AN ANALYSIS OF ARGUMENTATIVE WRITING OF THE FIFTH SEMESTER STUDENTS OF ENGLISH STUDY PROGRAM OF UNIVERSIDADE DILI IN ACADEMIC YEAR 2017.
}

\author{
Emilia Dos Santos De Jesus. \\ Reg. Id. 1611070027, Graduate English Education Program, Post Graduate Program, Nusa Cendana University, \\ 2017.
}

\section{Manuscript Info}

Manuscript History

Received: 01 July 2017

Final Accepted: 03 August 2017

Published: September 2017

Key words:-

argumentative writing, cohesion, coherence, grammar.

\begin{abstract}
Dos Santos de Jesus, Emilia. 2017. "An Analysis of Argumentative writing of the Fifth Semester Students of English Study Program of Universidade Dili in Academic Year 2016/2017". Supevisors: (I) Prof. Feliks Tans, M.Ed., Ph.D, (II) Dr. Agustinus Semiun, MA.

There are two problems to be answered in this writing, namely how the fifth semester students of English Study Program of Universidade Dili write argumentative texts and what their problems are in writing argumentative texts.

This writing aims at analyzing students' argumentative writing and finding out their problems in writing argumentative texts.

This study employs descriptive qualitative method. It describes deeply the findings related to the aims of study above. The data of this result is taken from the written forms of argumentative texts by the fifth semester students of English Study Program of Universidade Dili. The research shows that the students' argumentative writing is cohesively, coherently, and grammatically correct. However, some other mostly students present in cohesive, incoherent, and grammatically incorrect argumentative texts. Furthermore, there are several problems faced by the students in writing argumentative texts, namely: transferring ideas in writing, lack of vocabularies, problem in using grammar, difficulties to start writing, lack of reading sources, problems in organizing their writing, and inconsistently in developing idea.
\end{abstract}

Copy Right, IJAR, 2017,. All rights reserved.

\section{Introduction:-}

English is a language for international communication and it is used by most people around the world. As a language, there are some elements and skills of English language. These elements are pronunciation, vocabulary, structure and grammar that consist of eight parts of speech. Besides, knowing the elements of English language is not enough, but learners also realize through the four language skills that have to be developed namely listening, speaking, reading and writing.

Writing is a language skill. As a skill, it needs to be practiced every time.

Ten minutes per day for writing, for example, is a good duration to practice and improve one's writing skill. The frequent practice may make writer accustomed with how to develop a good writing product. In short, to become 
good writers is not easy process that the writers must attempt to write frequently in order to improve their writing skill.

An argumentative writing contains several important parts namely claim, reason and evidence, warrant, acknowledgement and response (Anonymous, 2008: 3). The first part is claim. Claim should be conceptual, clear definition and require good reasons. Therefore the audience should be able to agree and convince the writer's statement. The second part is reason and evidence. Reason and evidence help to convince the reader. Evidence offers tangible support for reason. When stating the reasons, the writer has to choose the best reason to support the evidence to convince the audience. The third part is warrant. To convince the reader, the reason and evidence that is presented by writer for maintain the claim need to be connected through warrant. Warrant expresses general principle in a way that influences or explains the writer's judgment in specific case. The last part is acknowledgement and response. Acknowledgement and response could be included in argumentative writing in order to produce trust, moderate objection and demonstrate the experience in a wide field or discipline.

In mastering of writing argumentative text, the writer must ascertain some aspects in writing argumentative. These aspects are stressed here namely organization of writing, elements of argumentative writing, cohesion and coherence features, grammar, vocabulary et cetera more over he or she as a teacher or lecture. Fifth semester students of English study program of Teacher Training and Educational Faculty of Universidade Dili are candidates of teachers or lectures. As a teacher or a lecture must have ability in writing argumentative text. If the teachers or lectures master in writing argumentative text then he or she could teach argumentative writing. Because of argumentative writing is taught since elementary school up to higher education. In other words, if teachers or lecturers do not master in writing argumentative text how could they teach the students.

Furthermore, based on observation at the fifth semester students of the English study program in Universidade Dili, the researcher found any grammatical errors done by the students in argumentative writing, such as many man, that changes and it easier. Phrase many man must be many men, because it indicates plural forms. Phrase that changes should become those changes since word changes is plural then demonstrative should be in plural as well. Another phrase is it easier, is not appropriate in form. This should be it is easier because subject it and complement easier should be linked by to be $i s$.

Based on this finding, the research intends to investigate the argumentative writing of the fifth semester student of English study program of Universidade Dili under the title "An Analysis of Argumentative Writing of the fifth semester students of English study program of Universidade Dili in Academic Year 2017.

\section{Research Questions:-}

This research attempts to answer the following questions:

1. How do the Fifth Semester Students of English Study Program of Universidade Dili write Argumentative text?

2. What are the problems faced by the Fifth Semester Students of English Study Program of Universidade Dili in writing argumentative text?

\section{Literature Review:-}

\section{General Concepts of Writing:-}

Writing is a physical and mental activity that is done by the writer in pouring the ideas in written form. Nunan (2003:38) states that writing has three definitions, they are; the first, writing are both a physical and mental act. It means that writing is the physical act of committing words or idea, whether writing on the paper or a message types into a computer. Meanwhile, a mental act means writing is the mental work of inventing ideas, thinking about how to express them and organizing into statement or paragraph to be clear to a reader. The second, writing is both to express and impress. It means that the writer shows his or her feeling or opinion and causes the reader to admire, feel happy and interested for what is written by the writer. The last, writing is both a process an product. The process means the writer imagines, organizes draft, edits, reads and rereads and then the writer could product the essay, letter, story or research report.

Kolin (2008:28) also defines that writing as a fluid process. It means that writing is dynamic and not static. It enables readers to discover and evaluate the writer's thought. Moreover, Tans (2014:4) states that writing is a means of communication in which a writer expresses his or her ideas, feelings, and skills as the contents of his or her writing. The content of his or her ideas should be clear so that the readers are easy to understand what is written. 
Based on the explanation above, the writer concludes that writing is a process of physical and mental act to express the ideas and thoughts that are `stated clearly in order to make the readers easy to understand and comprehend.

\section{Writing process:-}

Process means a series of action in order to achieve a result. Writing needs process to create a good writing. This process involves how the writer gathers information, planning, drafting, revising and editing what the writer has written to ensure that it is suitable for the readers (Kolin, 2008:28-37).

\section{Researching:-}

Researching means formal work undertaken systematically to increase the stockof knowledge. A research project can be used to develop further knowledge on a topic, or in the examples of a school research project, they can be used to further a student's research process to prepare them for future jobs or report. (Warner,1986: www.Wikipedia). John Creswell also (Wikipedia) stated that, research is a process of steps used to collect and analyze information to increase our understanding of a topic or issue.

\section{Planning:-}

Planning is the process of thinking about and organizing the activities required to achieve a desired goal (www.Wikipedia). For most writers, getting started is the hardest part of the job however if a writer feel more comfortable and confident therefore something will be easy to done (Kolin, 2008:29). Getting started is easier if a writer have researched his or her topic because the writer has something to say and to build up on his or her paper.

\section{Drafting:-}

If the writer has done his or her planning carefully, the writer will find it easier to start the first draft. When drafting, the writer converts the words and phrases from outlines, brainstormed list or clustered groups into paragraphs. During drafting, the writer will see some overlap as the writer looks back over his or her list or outlines ton shape his or her document. The writer does not expect to wind up with a polished, complete version of his or her letter, report, or proposal after working only one draft. In most cases the writer has to work through many drafts, but each draft should be less rough and more targeted than the preceding one. The following are some suggestions to help drafting go more smoothly and efficiently (Kolin, 2008:30-33).

1. In an early draft, write the easiest part first. Some writers feel more comfortable drafting the body or middle of their work first.

2 Working on a later draft and do not worry about spelling, punctuation, or the way a word or sentence sound. Save those concerns for later stages.

3 Allow enough time between draft therefore the writer can evaluate his or her work with fresh eyes and clear mind.

4 Get frequent outside opinions. Show writing to fellow student, a co-worker or maybe a supervisor for comment. A new pair of eyes will see many things are missed by the writer. Collaboration is essential in the workplace.

\section{Revising:-}

Revision is an essential stage in the writing process. It requires more than giving writer's work quick glance. The writer does not be tempted to skip the revision stage because the writer has written the required number of words or section or because the writer thinks it has put in too much time already. Revision is done after the writer produces a draft that the writer thinks convey the appropriate message for the audience. The quality of memo, letter, or report depends on the revision that is made by writer.

Like planning or drafting, revision is not done well in one big push. It involves over a period of time. Make sure that the writer must has enough time to do it carefully. The following are some stages in doing the revising (Kolin, 2008: 33-37).

1. Avoid drafting and revising in one sitting. If possible, wait at least a day before start to revise.

2. Asking a co-worker or friend familiar with the topic to comment on writer's working

3. Plan to read revised work more than once. When the writer revises it means that the writer reviews, rethinks, and reconsiders entire document. The writer asks questions about the mayor issues of content, organization and tone. Revision involves going back and repeating earlier steps in the writing process. 
Revision means asking again the questions that have already asked and answered during the planning and drafting stage. During the process, the writer will discover gaps to fill, points to change, and errors to correct in writer's draft. Revision gives the writer second, third or fourth chance to get things right for the writer's audience.

\section{Editing:-}

Editing is quality control for reader. Editing is done after the writer is completely satisfied make all the big decision about content and organization, that the writer has said what the writer wants to, where, and how the writer intends for audience. When editing, the writer will check for sentences, word choices, punctuation, spelling, grammar and usage, and clarity.

Editing is same with revising. The writer does not skip or rush through the editing process. Style, punctuation, spelling, and grammar are the great matters deal to the readers (Kolin, 2008:37). If the writer's work is hard to read or contains mistake in spelling or punctuation, readers will think that the writer's ideas and research are also faulty.

\section{Kinds of Writing:-}

\section{Descriptive Writing:-}

\section{General Definition of Descriptive Writing:-}

Tans (2014:63-66) expresses that descriptive writing is a piece of writing that describe an object, a person or thing based on observation, feeling and experience. Moreover, Kane (2000) in Purna (2014:24) sates that descriptive writing is about sensory experience, how something looks, sounds tastes. Furthermore, Pardiono (2007:34) says that descriptive writing is a type of written text, which has the specific function to give the description about an object namely human or non human in order to help the people perceive it through words.

\section{Generic Structure of Descriptive Writing:-}

In writing descriptive text, the writer should focus on generic structures namely identification, description, and conclusion (Anderson and Anderson in Purna, 2014:25) and also grammatical patterns (Pardiyono, 2007: 33). Those aspects are described below.

\section{Identification}

Identification (introduction) is a general opening statement in the first paragraph or the first sentence that introduces the subject of the description to the audience (Anderson and Anderson in Purna, 2014:25). It can give the audience brief details about when, where, who, or what are the subject described.

\section{Description}

Description is a series of paragraph about the subject where each paragraph usually begins with a topic sentence that is contained in the entire of the paragraph (Anderson and Anderson in Purna, 2014:25). Moreover, each paragraph should describe one feature of the subject and all paragraphs build the description of the subject. The description can be physical appearance of the subject, the qualities of the subject like degree of beauty, excellent or value, and other characteristics of the subject which is like the unique of the special aspects that the subjects has.

\section{Conclusion}

In this part, the writer concludes the text or restates the identification or description. A conclusion is not absolutely necessary however, it is often very helpful to the reader because it usually concludes signals the end of the text (Anderson and Anderson in Purna, 2014:25) in addition, it reminds the reader of the important point or in other word it is to emphasize the reader to imagine the subject.

4. Grammatical Patterns

Grammatical patterns in writing descriptive text are also important. Grammatical pattern of descriptive writing usually use verb which are in the present tense or the verbs which are infinitive (Pardiyono, 2007:33). Moreover, to describe the features of the subject, the using of adjectives is very necessary because it explains how the subject is described. Adjectives usually give sensory details about how something feels, tastes, smells, and looks like.

\section{Expository Writing:-}

Christy (1986:130) in (Tans, 2014:69) states that expository writing is a writing that is constructed based on any realities which are factual. There are two major categories of expository writing Tans (2013:69). The first, the writer gives the explanation about reason for a proposition or a statement and judgment of it. The second, the writer describes a proportion or statement more completely developed. This type of writing can concluded an essay, newspaper and magazine articles and textbook. 
In writing expository text, a writer should include some elements like thesis statement, arguments, writer's reiteration and grammatical patterns ( Pardiyono, 2007:216). Thesis statement is a controversial statement that contains hot topic and showing the position of writer in responding that topic. Next, arguments include opinion based on the reality that has acknowledged the correctness by public. While reiteration describes about the writer's conclusion that is strengthen the thesis statement. The last, grammatical patterns by using the present tense, past tense, verb of being, verb having, verb of doing and conjunction.

\section{Persuasive Writing:- \\ General Definition of Persuasive Writing:-}

Persuasive writing is a form of writing in which the writer uses words to convince the reader that the writer's opinion is correct in regards to an issue Martutik et al (2006:42). Kamalisa et al (2012) argue that persuasive writing is a piece of writing aims to persuade the reader to do something based on the author's wishes that can be proved with the data or facts.

In summary, persuasive writing is a writing that attempt to persuade the reader by stating facts, giving logical reasons, using examples and quoting experts.

According to Dunbar et al (1991) in Tans (2014:73), there are several guidelines for more effective in writing persuasive text namely;

1. Defining the problem. It means the writer states his/her problems that he/she wants to raise in his/her writing.

2. Analyzing the problem fully. It means the writer describe or explains the problems that are stated before in his/her writing.

3. Including a full recognition of the opposing point to show the strengthen and weaknesses. This statement means the writer includes his/her opposition point to strengthen and weaknesses his/her problems.

4. Giving the solution of the problem by giving convincing material to strengthen and weaknesses the argument. This part means the writer gives the solution what is stated in the problem statement and gives an example or an evidence to convince the readers.

5. Appeal the readers' interest and sympathy. It means the writing should be interesting and expressing the sympathy to the readers. The interesting and sympathy should be expressed in the writing. It starts from the problems statement, body of the writing, and the conclusion.

\section{Narrative Writing:-}

\section{General Definition of Narrative Writing:-}

Meyers (2005) in Karolina (2006:25) states that narrative is one of the most powerful ways of communicating with others. Also, narrative writing is defined as a piece of writing contains about the story (Martutik et al, 2006:45) and entertains or informs the reader or listener (Anderson, 1997, in Karolina, 2006:25)

\section{Generic Structure of Narrative Writing:-}

Neo (2005) in (Karolina, 2006:27) states that a narrative has a structure, a shape or a pattern. Anderson (1997) in (Karolina,2006:27) state that there are several steps in constructing a narrative, they are:

a. Orientation or exposition

The readers are introduced to the main characters and possible some minor characters. Some indication is generally given of where the action is located and when it is taking place.

b. Complication or rising action

The complication is pushed along by a serious of events, during which we usually expect some sort of complication or problem to arise. It is not so interesting if something unexpected is not happened. This complication involves the main characters and reaching their goal.

c. Sequence of event

This tells about how the character reacts to the complication. It includes their feeling and what they do. The event can be told in chronological order or with flashback. The audience is given the narrator's point of view.

d. Resolution or falling action

In this part, the implication is resolved for better or worse, but it rarely left completely unresolved. This type informs us how the story ends.

e. Reorientation

It is an optional closure of event. 


\section{Argumentative Writing:-}

Argumentative is a crucial aspect of writing skill acquisition. The ability of formulating arguments is convincing the audiences or reader to believe the writer's statement. Tans (2014:72) and Martutik et al., (2006:39) expresses that argumentative writing is a writing that is uttered by a writer to give some reasons why she or he agrees or disagree with certain proportion or statement, ideas, people or things and try to influence the reader to accept that statement. In developing an argument we need to express idea, opinion or views and conclude. Salmon (1984) in Martutik et al., (2006:39) says that argumentative as a set of sentence that is arranged as evidences which support the other sentence in a text. An argumentative writing requires a writer to defend a position on a topic using evidence from personal experience, literature, historical example and research to support his or her perspective or statement.

Based on the explanation above, the writer concludes that argumentative as a piece of writing that consists of introduction, body and conclusion that could influence the reader or listener based on real evidence logical consideration.

\section{Parts and Elements of Argumentative Writing:- Parts of Argumentative Writing:-}

There are three parts in writing argumentative text; they are introduction, body and conclusion (Endy, 2011:1). The first is introduction. In introduction, the writer should start with an opening statement provides a bridge to thesis statement. Also be sure to avoid general statement that make unsupportable claim. The second is body. Each paragraph in the body should star with a topic sentence. The topic sentence should announce the argument of the paragraph and make clear how the paragraph should then present and explain evidence that will support the topic sentence. Each paragraph should develop one distinct idea. If a writer squeezes too many different ideas into one paragraph, the topic sentence will be muddle. If a writer sees this happening, split the paragraph into two, each one starting with its own topic sentence. The last is conclusion. Conclusion provides a simple summary of main argument. By the end of the body, a writer uses the conclusion to raise broader ideas that flow from argument and evidence. After presenting careful evidence in the body a writer has earned the right as an author to share broader ideas to readers in conclusion.

\section{Elements of Argumentative Writing:-}

According to Martutik et al., (2006: 40-42), there are six elements in argumentative writing namely, statement, reason, verification, backing, rebuttal, and modal. Statement is an opinion is convinced by the writer or speaker and stated it into the writer that can be accepted with the reason which is proved. Statement is the purpose that achieved by the writer or speaker. There are three kinds of statement that is (a) statement of fact, (b) statement of value, and (c) statement of policy. Reasons which refer to evidence that are needed to support the statement. Reason or proponent evidence can be statistic data, example, illustration, logical thinking, observation, experiment and general knowledge material. Verification is general statement that is used to maintain the statement and reason. Backing is the criteria that is used to support the statement and also reason such as convince experience, reality, the statement of expert, result of research, or result of interview. Modal is the words or phrases that show certain and possibility that are marked by certain, sure, of course, apparently, maybe, seemingly, possibility, very possible, and logical. Rebuttal is the statement that is used to weaken and strengthen the statement that are marked by except, if...so and if.

Related to the statement above, Tolumin's theory in (Hilloks, 2010:26) expresses that the basic conception of argumentative writing includes several elements as a claim based on evidence support the claim, backing supporting the warrant, qualifications and rebuttals or counterarguments that refute competing claims

\section{Research method:-}

In this research, the researcher applied descriptive qualitative method. The aim of this method is to describe the characteristic of phenomena. The description of phenomena employed narrative description. Narrative description means the researcher explain the phenomena situation and the fact completely and comprehensively by using words and sentence in narrative text.

Qualitative

In qualitative study, the researcher played a very important role. This role is called human instrument. Human instrument in qualitative study consists of some tasks. The first is deciding the focus of research; the second is 
selecting data sources; the third is collecting data; the forth is evaluating, analyzing, and interpreting the data and the last is reporting and finding. (Sugiono, 2014:306)

\section{Findings:-}

In this writing, the researcher displays some findings of this research and discusses them to answer the research problems in previous chapter. The findings are classified into how the fifth semester students of English Study Program at Universidade Dili write argumentative text and their problems in writing argumentative text. Those are discussed below.

\section{Student's Ways of Writing Argumentative Text:-}

In this part, the researcher analyzes how the fifth semester students of English Study Program of Universidade Dili write English argumentative writing. It is found that the students' writing are cohesively, coherence and grammatically correct and incorrect. Furthermore, students' writing are incohesively, incoherence, and grammatically incorrect. These aspects are described below

\section{Cohesively Written Argumentative Text:-}

In this part, the researcher discusses students cohesively write argumentative text by using cohesive devises. Cohesive devises in this writing focus on grammatical cohesion. There are four types of grammatical cohesion namely substitution, reference, conjunction, and ellipsis. Based on the result finding, the researcher found that there are three kinds of grammatical cohesion that are used by the fifth semester students of English Study Program of Universidade Dili in their argumentative writing. They are reference, conjunction, and substitution. These grammatical cohesions are described below.

\section{References:-}

In analyzing the references in argumentative writing, the researcher employs the theory of Halliday and Hassan (1967: 37) that divide reference into three types; they are personal, demonstrative, and comparative references. The result findings show that, there are two kinds of references are used by the fifth semester students of English study program of Universidade Dili; they are personal pronoun and demonstrative adjective references. Personal pronoun consists of I, my, me, myself, we, our, us, they, your, her, and his, while demonstrative adjective comprise of this, that, these, those, here, and the. In addition, comparative references consist of so many, better and other.

\section{Personal Pronoun References:-}

This section the researcher investigates the references of personal pronouns I, my, me, myself, we, our, us, they, it, their, them, your, her and his.

I

This part discusses the reference of personal pronoun $I$. This reference is displayed in the following writing.

"I totally agree with the title given that women are difficult to access education in Timor Leste because their parents don't know the benefit of education. I don't agree because...,"

The word $I$ in line one and two refers to the writer. This reference is called exophoric reference because; this reference does not exist in the text. It refers to out of the text.

\section{Demonstrative Adjectives references:-}

This section the researcher presents the references of demonstrative adjectives this, that, these, those, here and the. The following writing presents these demonstrative adjective references

\section{Those:-}

This section the writer discusses the demonstrative adjective 'those'. It present in the following writing.

"Women are difficult to access education because of culture. Difficult those women to access the education because values in culture that state women should stay at home, wash clothes, cooking and clean house".

The word 'those' in this writing refers to some women. This reference is called cathaphoric reference.

\section{Comparative References:-}

This part discusses comparative references in argumentative writing. Comparative references comprises 'better'. This reference is displayed in writing below.

"Some girls are better than boys in intellectual ability, some women have better profession than men and we should value the right of women to get the formal education" 
The comparative reference in this writing is 'better'. The word 'better' in this writing is used to compare the women's abilities. The word 'better' refers to women's abilities. The kind of this reference is called anaphoric reference

\section{Identification of the field problems:- Uncohesively of Using References:-}

In this part, the researcher displays incorrect of using references. There are two kinds of references namely personal pronoun references and demonstrative adjective references. The personal pronoun references consist of it, your, her, and their, while demonstrative adjective references consist of this, that, and here. These references are shown and explained below.

\section{Uncohesively of Using Personal Pronoun References:-}

Her:-

This part discusses the personal pronoun 'her'. The writer demonstrates unsuitable of applying reference of personal pronoun 'her'. This problem illustrates in the following sentence.

"Finally, we should value the right of women to get the formal education; this means that women will learn new things to educate her children at home".

The writer states that "Finally, we should value the right of women to get the formal education; this means that women will learn new things to educate her children at home". The word 'her' in this writing refers to women but, it is inappropriate reference. 'Her' in this writing indicates plural noun nevertheless; something that is referred is 'women'. The word 'women' indicates plural noun. Thus, the appropriate reference might be 'their'. Therefore, the sentence above could be "Finally, we should value the right of women to get the formal education, this means that women will learn new things to educate their children at home".

\section{Incoherently Inter Paragraph:-}

In this part, the researcher investigates the coherency between paragraphs. Researcher found that there is a student writing that have incoherency between paragraphs. The writing displays incoherency in developing ideas. It performs in the writing below.

"Normally, education is very important for Timorese women. Timorese women have right to access education to develop their life. Base on the Timor Leste laws in constitutional Republic Democratic of Timor Leste (RDTL) 17 article says that men and women equal gender.

In addition, education is as a good way for Timorese women. Education also as a shine way to express their ability and develop their life.

In conclusion, the education is very important for us. Because base on constitution of RDTL laws give way for women to access education. Therefore i disagree with the title above.

In this writing the writer just offers some reasons, but he/she does not develop it. The second paragraph this writing has not supporting ideas. The production of this writing shows that, there is no supporting idea in this writing.

Grammatical Incorrect Writing Argumentative Text:-

Grammar is basically about how the words are combined to form a sentence. The researcher found that the students' argumentative writings are grammatically correct and incorrect. This part, the researcher focuses on several grammatical errors that are found in students' argumentative writing. The grammatical errors are analyzed according to surface taxonomy strategy by Dullay, Burt, and Krashen, (1982:155) who presents four kinds of errors. The errors include omission, addition, misformation, and misordering. There are three kinds of errors are found in students' argumentative writings, they are omission, addition, and misformation.

\section{Omission:-}

Omission error is characterized by the absence of items that must be presented in a well formed utterance. Based on the research findings, there are several omission errors in students' argumentative writing. They are illustrated and explained such as follows.

"Because girls are better than boys, as it have been proven that girls are smart, and one reason because girls learn better. This is because women are better organize, open, and considerate. 
Grammatical error in this writing is the case of passive voice. In constructing passive voice, the verb should be in past participle or verb three. The rule for forming passive voice is subject + to be $+v 3$. Consequently, these grammatical errors might be women are better organized, opened, and considerate. Besides, omission error is found in the following writing.

"As it have been proven that girls are smart"

\section{Addition:-}

Addition error is characterized by the presence of item which must not be presented in a well formed utterance. There are several additional errors found in students writing.

"Moreover, environment and social intercoms include to make women's parents cannot gives permission to their daughters to access education"

Based on this writing, the writer adds morpheme $s$ at the end of word give. This addition is inappropriate. In brief, the morpheme $s$ at the word give might be omitted and this writing should be cannot give permission.

\section{Misformation:-}

Misformation error is characterized by the use of the unacceptable forms of the morpheme or structure. Based on the researcher findings, the researcher found that there are several information errors of students' writing. These are performed in the following writing.

"Many women become a good leader in Timor Leste like Minister of Education, Vice minister of education and so on".

The writer presents the word a good leader after plural noun women. This formation is not correct. The accurate formation is the noun 'leader' might be plural noun. The plural form of leader is leaders and without a word $a$. $a$ is used to singular noun. This writing might be "many women become good leader".

\section{Students are Difficult in Transferring Ideas in Writing:-}

Transferring ideas is one of problems of students' writing. In this case, the students face some problems in transferring idea namely the students write without ideas development or supporting ideas.

\section{Students Lack of Vocabularies:-}

The using of vocabulary is important in writing. In writing argumentative text, the students face some problems about vocabularies. The first, the students present Tetum language in their writing. For example, the students offers democratika for democratic.

\section{Problem in Using Grammar:-}

This grammar is one of the problems of students in writing argumentative text. There are some errors in using grammatical namely errors in omission, errors in addition, and errors in misformation.

\section{Students Lack of Reading Source:-}

Reading source is important in writing. If we are lack in reading, thus our writing is not good. It is one of the problems in writing. The fifth semester students of English Study Program of Universidade Dili also have this problem in writing argumentative text. Based on the result of interview, the students said that they lack of reading the source about the Education system in Timor Leste. Thus, it made them difficult in expressing their ideas in writing argumentative text. Expressing the ideas in writing is not easy if we do not read the sources that we want to write. If it is happened to us therefore, we are not only difficult in transferring the ideas but also we do not know how to write.

\section{References:-}

1. Asih, Anggrani., Wijayanti, Hapsari, Sri., Hendrawati, Sri, Endang, Ika., Candrayani, Amalia. (2006). Mangasah Ketrampilan Menulis Ilmiah di Perguruan Tinggi. Yogyakarta: Graha Ilmu.

2. Bachman, F. Lyle. (1990). Fundamental Consideration on Language Testing.

3. New York: Oxford University Press.

4. Anonym, (2008). Writing Module Three: Five Essential parts of Argumentative.

5. Cho, Hee Youn, \& Shin, Jeong- Ah. (2014). Cohesive devices in English writing textbooks and Korean learners' English writing. Korea: Seoul National University. 
6. Chase, Billian, Beth. (2011). An Analysis of the Argumentative Writing Skills of Academically Underprepared College Students. Colombia: Colombia University.

7. Dueraman, Bayatee. (2007). Cohesion and Coherence in English Written by Malaysian and Thai Medical Students. Southern Thailand: Cultural Change Conference.

8. El- Gazzar, Kamal, Nevine. (2006). Lexical Cohesive Devices in Arab Students' Academic $\quad$ Writing: Implication for Teaching Vocabulary. American University of Sharjah.

9. Erom, Kletus. (2010). "Applied Linguistic and Research Thesis Writing. Kupang: Teacher Training and Educational Sciences Faculty Widya Mandira Chatolic University.

10. Endy, Chris. (2011). How to write an Argumentative Essay. Los Angeles: California State University.

11. Garing, G. Alphie. (2014). Coherence in the Argumentative Essay of Year College of Liberal Arts Students at De La Salle University. Manila: $\quad$ University of Batangas

12. Hameed, Tahseen, Hind. (2008). Cohesion in text: A discourse Analysis of News Articlein Magazine. Diyala University Haliday, M. A. K. \& Hasan, R. (1976). Cohesion in English. London: Longman.

13. ............. (2006). Cohesion and Coherence: Linguistic Approaches. Netherlands: Utrech University

14. Iqbal, Mudassar., Mehmood, Asar., Jabeen, Iqra. (2013). Ellipsis, reference and Substitution as Cohesive Devices the Bear by Anton Chekhov. Pakistan: University of Shargoda.

15. Jr. Hillocks, George. (2010). Teaching Argument for Critical Thinking and Writing: An Introduction. The University of Chicago Kollin, C. Philip, (1994). Successful writingat work. Fourth Edition.

16. United States of America: Heat and Company.

17. Karolina Intan. (2006). Teaching Narrative Text in Improving writing to the tenth Grade Students os SMA NEGERI 1 Petarukan, pemalang Universitas Negri Semarang. http://lib. Unnes.ac.id/1180/1.2081.pdf. Access on Sunday, December 20,2015. 05.21 am Martutik, Arifin, Bustanul, Rani, Abdul. (2006). Analysis Wacana Sebuah KajianBahasa Dalam Pemakain. Malang: Bayumedia Publishing.

18. Mc Carthy, Michael. (2000). Discourse Analysis for Language Teachers.

19. New York: Cambridge University press.

20. Martinkova, Petra. (2010). Means of Coherence and Cohesion in Spoken and Writen Discourse.

21. Nelson, Gerald \& Greenbaum, Sidney. (2002). An Introduction to English Grammar. Second Edition. London: Longman.

22. Nunan, David. (2003). Practice English Language Teaching. New York: McGraw-Hill.

23. Pardiono. (2007). Teaching Genre-Based Writing. Yogyakarta: Andi Offset.

24. Qoerol, Mercedes. (2001). Subtitution as a Device of Grammatical Cohession in English Narrative and it is Translation to Spanish. University of Jaume.

25. Salkie, Raphael. (1995). Text and Discourse. New York: Routledge.

26. Sugiono. (2014). Metode Penelitinan Kombinasi (Mix Methods). Bandung Alfabeta.

27. Siahaan, Sanggam \& Shinoda, Konso. (2008). Generic Text Structure. $\quad$ Yogyakarta Graha Ilmu.

28. Taringan, Guntur, Henri. (1987). Pengajaran Wacana. Bandung: Angkasa Tans, Feliks. (2014). Writing an Introduction. Kupang: Lima Bintang.

29. Yatsuke, Tomoko. (2009). The Nature and Working of Lexical Substitution in English Discourse. Japan: Aichi University of Education. 